\title{
periferio
}

\section{INTERVIEW \\ MIND THE GAP: PROMOTING \\ GENDER EQUALITY IN LEADERSHIP}

\section{Abstract}

With globalization, the technological and digital revolution, and the opportunities they bring, the world of work is significantly changing for women. To bridge the gender gap and give women economic empowerment, unstable livelihoods and incomes, new trade policies, environmental impacts and the growing informality of labor must be addressed. The good news is that leaders can improve equality at their business and reap the manifold rewards of diversity, if they are willing to walk the talk. This interview with Pakistani nonprofit leader and educator, Abaida Mahmood, examines the measures that are key to ensuring women's economic empowerment in the changing world of work. These include bridging the gender pay gap, which stands at 24 percent globally, addressing the gender gaps in leadership, challenging the barriers that prevent women from progressing and ensuring gender-responsive economic policies for job creation, implementing poverty reduction, and ensuring sustainable, inclusive growth. Abaida Mahmood is an English teacher and a trainer in London \& has led the charitable organization, Qurban \& Surraya Educational Trust, in Lahore, Pakistan since her father's founding in 2002. As an advocate for the vulnerable, her work has empowered and transformed the lives of many young girls from dependent women into contributing members of the society. She travels extensively and has presented workshops for students and adults internationally. As a motivational speaker, her work has inspired many women into taking on leadership roles. Her well-known workshop, "Home Grown Leadership Models for Female Leadership," is highly sought after and replicated by many educators globally. In this interview, Elizabeth C. Reilly, Professor and Chair of Educational Leadership at Loyola Marymount University in Los Angeles, California, USA, explores with Mrs. Mahmood the challenges and opportunities of promoting gender equality in leadership.

Keywords: gender gap; equality; leadership 


\section{periferio \\ ENTREVISTA \\ PENSANDO A LACUNA \\ ENTRE IGUALDADE DE GÊNERO E LIDERANÇA}

\section{Resumo}

Com a globalização, a revolução tecnológica e digital e as oportunidades que elas trazem, o mundo do trabalho está mudando significativamente para as mulheres. Para reduzir o fosso entre os gêneros e garantir às mulheres, a autonomia econômica, modos de vida e rendimentos estáveis, novas políticas comerciais, impactos ambientais e a crescente informalidade do trabalho devem ser abordadas. A boa notícia é que os líderes podem melhorar a igualdade em seus negócios e colher as múltiplas recompensas da diversidade, se estiverem dispostos a falar a respeito. Esta entrevista com Abaida Mahmood, líder e educadora paquistanesa, que atua numa organização sem fins lucrativos examina as medidas que são fundamentais para garantir o empoderamento econômico das mulheres no mundo do trabalho em mudança. Estas incluem a redução das disparidades salariais entre homens e mulheres, que representam $24 \%$ no índice global, desafiando as barreiras que impedem as mulheres de progredir e garantindo políticas econômicas sensíveis ao gênero para a criação de emprego, implementando a redução da pobreza e assegurando sustentabilidade e crescimento. Abaida Mahmood é professora de inglês e instrutora em Londres. Liderou a organização de caridade Qurban \& Surraya Educational Trust, em Lahore, Paquistão desde a sua fundação, em 2002, por seu pai. Como defensora de pessoas vulneráveis, seu trabalho fortaleceu e transformou as vidas de muitas jovens mulheres paquistanesas dependentes, que contribuem para membros da sociedade. Mahmood viaja muito e apresentou oficinas para estudantes e adultos internacionalmente. Como palestrante motivacional, seu trabalho inspirou muitas mulheres a assumir papéis de liderança. Seu conhecido workshop, "Modelos de liderança familiar para liderança feminina" é muito procurado e replicado por muitos educadoras em todo o mundo. Nesta entrevista, Elizabeth C. Reilly, professora e presidente de Liderança Educacional na Universidade Loyola Marymount, em Los Angeles, Califórnia, EUA, explora com a Sra. Mahmood os desafios e as oportunidades de promover a igualdade de gênero na liderança.

Palavras chave: lacuna de gênero; igualdade; liderança 

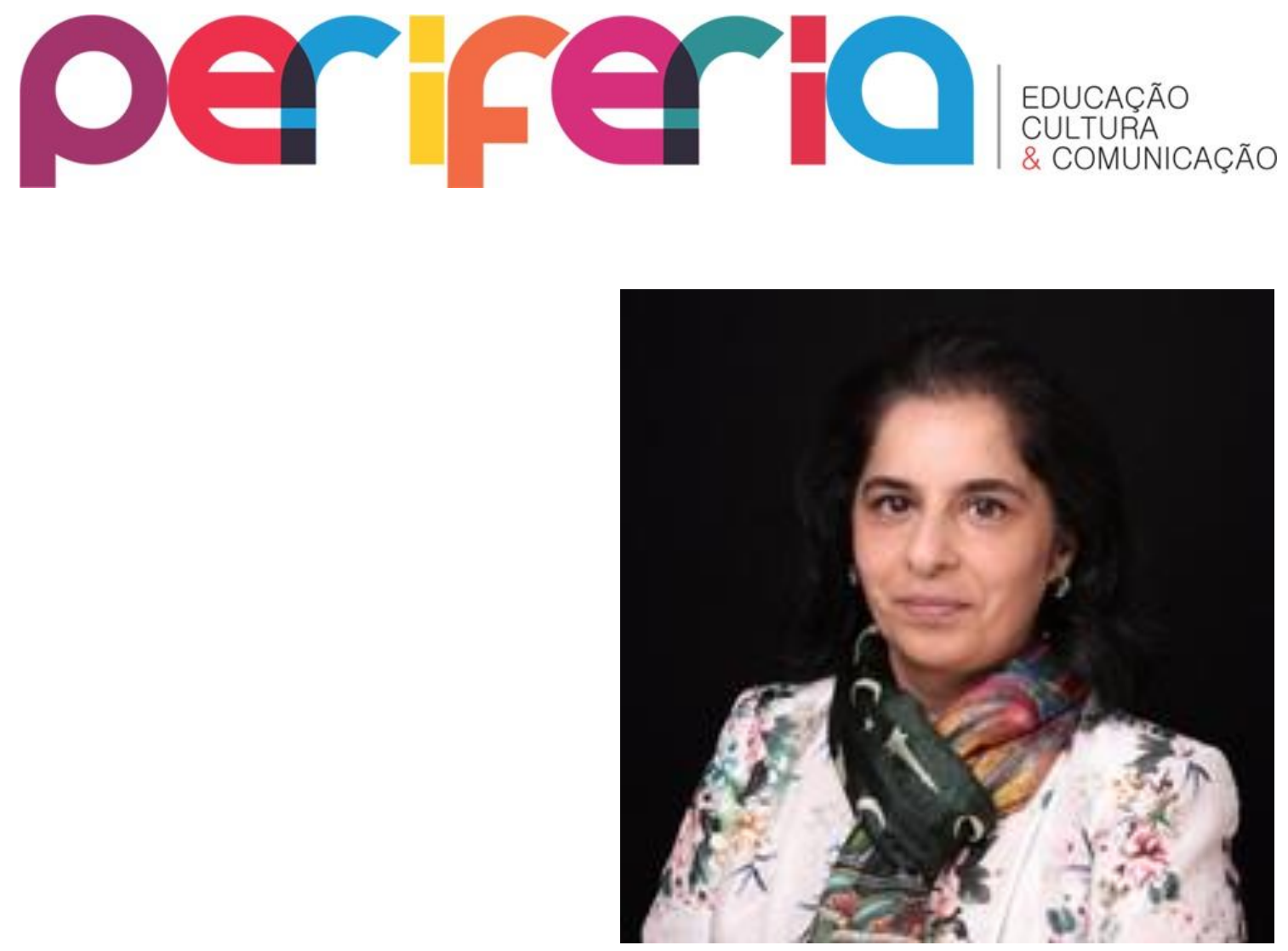

Abaida Mahmood

No nation can rise to the height of glory unless your women are side by side with you. We are victims of evil customs. It is a crime against humanity that our women are shut up within the four walls of the houses as prisoners. There is no sanction anywhere for the deplorable condition in which our women have to live. Muhammad Ali Jinnah. Founder of Pakistan.

\section{Elizabeth C. Reilly (Reilly) - In your work you talk about the gender gap and} advocate that we "Mind the Gap." Tell us more.

Abaida Mahmood (Mahmood) - The phrase, "Mind the Gap," is very commonly announced audibly or on signs while traveling on the London Underground railway system, often called "The Tube." When you step from the station platform onto the train car, there is often a huge space between the two. If you do not mind of that gap, you risk serious injury. For me it is not just an iconic phrase associated with London, but a phrase which has affected me as a woman. It is a constant reminder to all that we need to be cautious about the spaces that have been created purposefully to allow male domination.

The gap we need to mind in the $21^{\text {st }}$ century is the gender gap. It may be described as the difference between women and men as reflected in social, political, intellectual, cultural, or economic attainments or attitudes. Klaus Schwab, Founder and Executive Chairman of the World Economic Forum, wrote Periferia, v. 10, n. 2, p. 217-230, jul./dez. 2018 


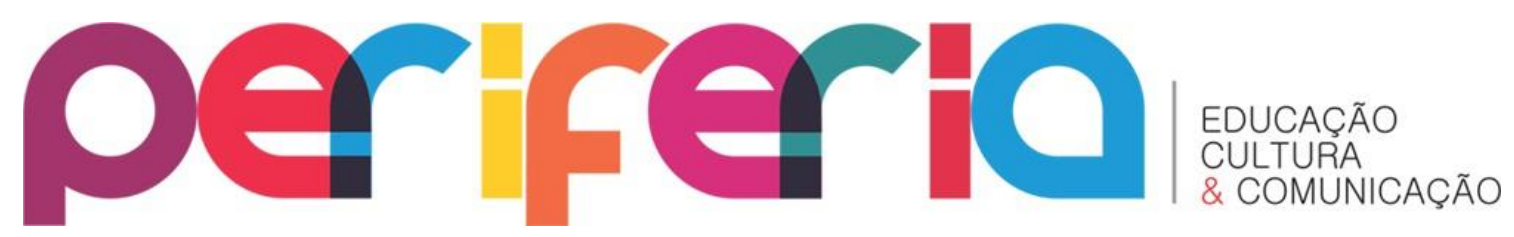

in its 2017 Global Gender Gap report, "The world is being deprived of a huge untapped resource." Despite progress on this issue, the gap between men and women across health, education, politics, and economics has widened.

(Reilly) - What do you mean when you say that sexism is the new apartheid? (Mahmood) - In his book, God has a Dream, Desmond Tutu explained the importance of combatting sexism. He wrote, "Ending sexism and including women fully in every aspect of society not only ends its own great evil-the oppression of women-but also is part of the solution to the rest of the world's problems." Women are half the world but they are still unfairly disadvantaged right from their birth. Almost all societies discriminate against the female population. Many countries seem to be doing well but it is apparent that male members are given more advantages then females. Lack of healthcare \& education facilities, economic denial and lower-class values are some of the obstacles facing girls in the world today.

Societies and economies thrive when there is gender parity. The untapped talent of women has a great impact on the growth of countries. The World Economic Forum's 2017 Global Gender Gap Report benchmarks 144 countries on their progress towards gender parity across four thematic dimensions: Economic Participation and Opportunity, Educational Attainment, Health and Survival, and Political Empowerment. It states that looking at the current trends, the overall global gender gap can be closed in exactly 100 years across the 106 countries covered since the inception of the Report, compared to 83 years in last year's report. In other words, the gap is ever increasing, not diminishing.

Iceland is at top of the list with narrowest gender gap. Iceland has had the overall smallest gender gap for five straight years. It ranks first in education and economic empowerment for women. To give you some idea of other key nations, the United Kingdom is at $15^{\text {th }}$ position. The United States is at $49^{\text {th }}$ position, while the Russian Federation is at $71^{\text {st }}$. Brazil is at $90^{\text {th }}$ position. China ranks $100^{\text {th }}$ position, the United Arab Emirates at $120^{\text {th }}$ position, and Syria at 


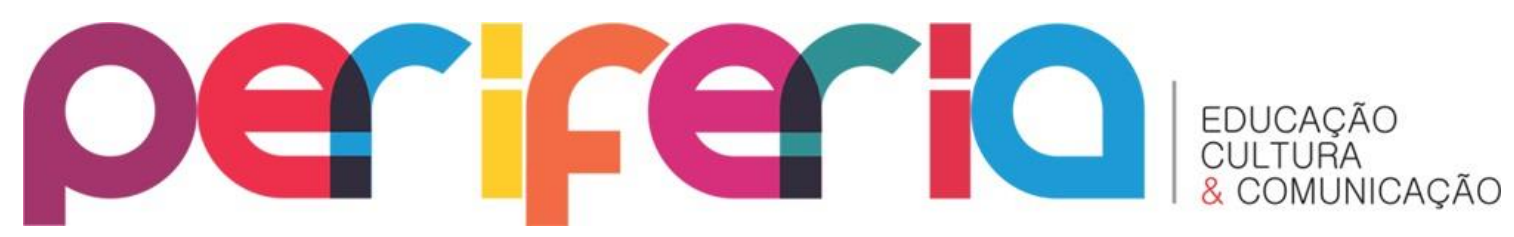

$142^{\text {nd }}$ position. Pakistan, where I was born, is at $143^{\text {rd }}$ position. Yemen is at last position, which is $144^{\text {th }}$. Clearly, there is a lot of work to do to mind the gap.

The United Nation's fifth Sustainable Development Goal is bold, broad, and important. It challenges the world to: “Achieve Gender Equality and Empower All Women and Girls." There are many factors that shape the goal and issues that need to be tackled to help achieve it. Investing in women is the most powerful investment that the world would make. Some of the issues that would help to tackle gender gap are gender gaps in leadership and in pay; barriers that prevent women from progressing; gender-responsive economic policies for job creation; and poverty reduction with sustainable, inclusive growth.

\section{(Reilly) - Could you talk further about the gender pay gap?}

(Mahmood) - More than ever before gender pay gap has been in the news and regulations. It can be termed as the percentage difference between average hourly earnings for men and women. In this day and age men are still being paid much more than women and their earnings are increasing every year. The pay gap is widening, despite various initiatives to break glass ceilings and salary reporting. Sadly, women who choose to be mothers have a price to pay which is further higher than the gender pay gap. Globally, women are robbed off $23 \%$ of their pay if they have children.

According to Fawcett Society United Kingdom, here are four big causes of the gender pay gap:

Discrimination - It is illegal, but in many places, women get paid less for doing exactly the same job or for doing the work of equivalent value. According to 2017 Equality and Human Rights Commission Report, around 54,000 new mothers are losing their jobs across Great Britain every year-almost twice the number identified in similar research undertaken in 2005.

Unequal Caring Responsibilities - In most cases women continue to play a greater role in caring for children, as well as for sick or elderly relatives. Therefore, women tend to select part time work, resulting in less pay and fewer progression opportunities. The pay gap is more significant for women in their 


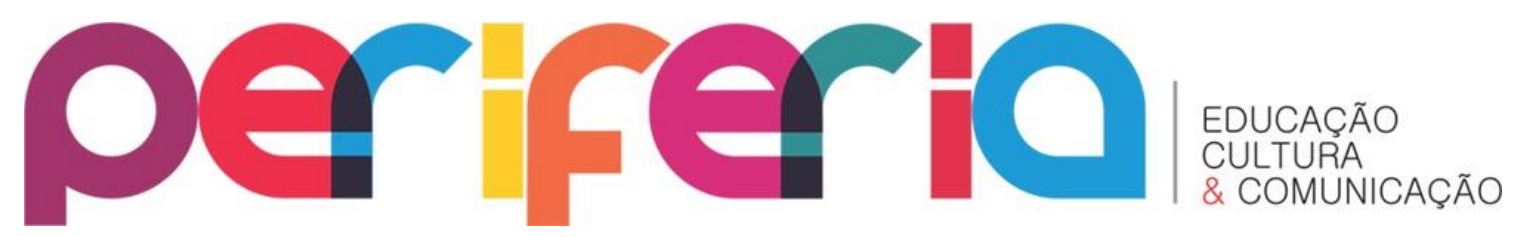

forties as women return back to work after raising their children and it is then that they find their male contemporaries are being promoted ahead of them.

A Divided Labor Market - Women are still more likely to be in low paid and low skilled jobs, affecting labor market segregation. Eighty percent of those working in the low paid care and leisure sector are women, while only $10 \%$ of those in the better paid skilled trades are women. Feminized sectors tend to be less valued and less well paid; women make up $60 \%$ of those earning less than the living wage.

Men in the Most Senior Roles - Men still dominate the executive and senior management ranks of major companies. MWM Consulting revealed that in the United Kingdom, women now hold 31.4 per cent of non-executive boardroom roles at FTSE 100 companies, up from 15.6 per cent in 2011 - but the executive pipeline has barely moved. Women executives represented 9.6 per cent of boards, a slight rise from 5.5 per cent four years ago.

The 2017 Global Gender Gap Report cites recent estimates that suggest economic gender parity could add an additional $\$ 250$ billion to the GDP of the UK, \$1,750 billion to that of the US and \$2.5 trillion to China's GDP. At the current rate of progress, though, the overall global gender gap will take a hundred years to close, while the gap in the workplace will now not be closed for 217 years. It is a gap the world cannot afford to ignore. According to the Wage Indicator data 2017 the GPG is highest in the Asian countries, with GPGs in the bracket between 30 and $40 \%$. The majority of countries are in the bracket between 10 to $30 \%$.

(Reilly) - How we can help close the wage gap?

(Mahmood) - Nations should approach this from a variety of perspectives: at the governmental level, at the private sector level, at the non-profit level, and at the individual level. I will focus here on governments and the private sector. Governments can enact many changes. Many nations have started to take the issue of gender gap seriously. Iceland's parliament, for example, has passed a bill that would require companies to document they offer equal pay to employees. The law, which is set to become a world first, aims to close the 


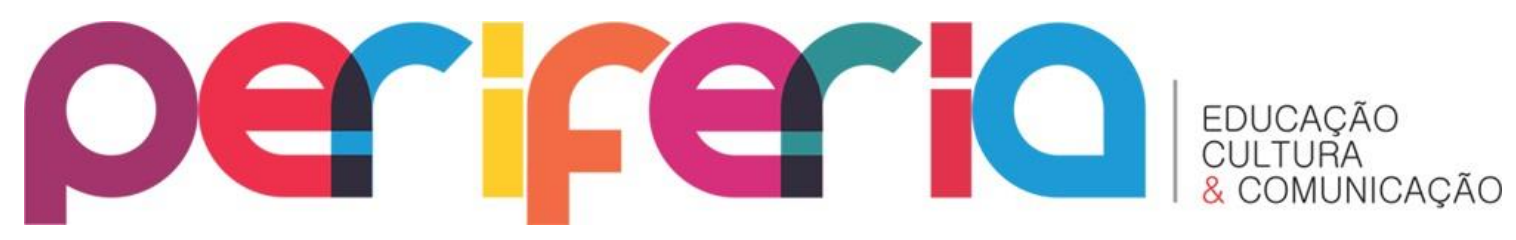

wage gap between men and women. Companies will face auditing and possible fines if they do not comply. Such practices should be followed by other countries if they are serious about tackling the gender pay gap. New rules to be introduced to force bigger employers to publish their pay gap and to actually raise the pay of the female employer if there is a gap. To subsidize child care to help mothers get back to work without worrying about the cost of care.

Companies must ensure that they have fair hiring practices based on merit and are free from gender bias. The should review the balance of men and women at the different management levels in the company. If there are fewer women the further up the ladder then search for female leaders and encourage them to join the company. To train the next generation of managers by creating an internal management training programs and offering the female employees a direct access to career building. If there is a gender pay gap then increase the salaries of the females and to abolish income disparity for the future employees. To establish a culture that is welcoming to people of all backgrounds

(Reilly) - What would you identify as barriers that prevent women from progressing?

(Mahmood) - Studying female leadership, I have noticed despite women facing a number of hurdles in their leadership journey, the barriers can be categorized as internal and external. Most barriers to our success are our mind sets and we are the only ones who can change them. The internal barriers include belief in oneself, coming out of one's comfort zone, asking for help, and staying put. Let me describe each of these.

Belief in Oneself. Women are very hard on themselves. They need to be reassured that they are capable, they need to believe in themselves and their leadership capacity. Leadership is more like a personal fear, once we overcome that fear we can achieve anything. They suffer from something which I have called, "Leadophobia." Women need to think of themselves as leaders, dream about standing where they want to be, and then work toward that goal. Nothing can stop them from reaching the peak. They should try to work on confidence-

Periferia, v. 10, n. 2, p. 217-230, jul./dez. 2018

DOI: $10.12957 /$ periferia.2018.33265 


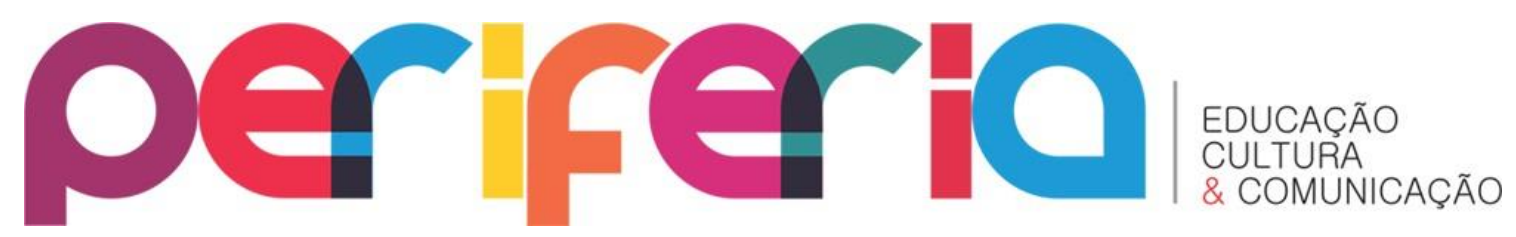

building and assertiveness training. We mistake assertiveness for being pushy. We need to understand the true meaning-the ability to honestly express your opinions, feelings, attitudes, and rights, without undue anxiety, in a way that does not infringe on the rights of others.

Coming Out of Your Comfort Zone. Women are frequently quite content with their current status. They are reluctant to move out of their comfort zones. After all, it is comfortable in there. Our comfort zone is familiar. They know the thoughts and feelings that reside in that zone. They know the kind of life that exists there. A comfort zone is like a bubble. It feels protective, but it also might be claustrophobic because it prevents change and growth. Leaving their comfort zone gives them a better understanding of who they are and what they like when they expose themselves to new experiences. Sometimes, they are not even that comfortable in their comfort zone. But they still stay there. They worry that things outside the comfort zone will be worse. They worry about the unknown and women tend to fear the unknown more than men.

(Reilly) - Please, could you list some strategies for coming out of our comfort zones?

(Mahmood) - Of course. Willingness to make a fool of oneself; Knowing that worst thing that can happen when trying something new is possible failure; Facing the fears; Becoming comfortable with taking risks as there is no alternative for experience; and Enjoying the unknown.

Asking for help - Women often feel like they cannot or should not ask for support or help with career development. They think that by asking for support they are admitting they fall short of the required standard. They believe that it can appear as a sign of weakness to their peers that they are not ready for the next rung on the career ladder. They do not have to seek help from women only as men can make equally good mentors.

Women need to remember to:

- Be coachable and passionate;

- Surround them self with encouraging \& positive people;

- Have many mentoring moments in your career by reaching out to people one admires. Finding a good mentor can be as important to one's career 


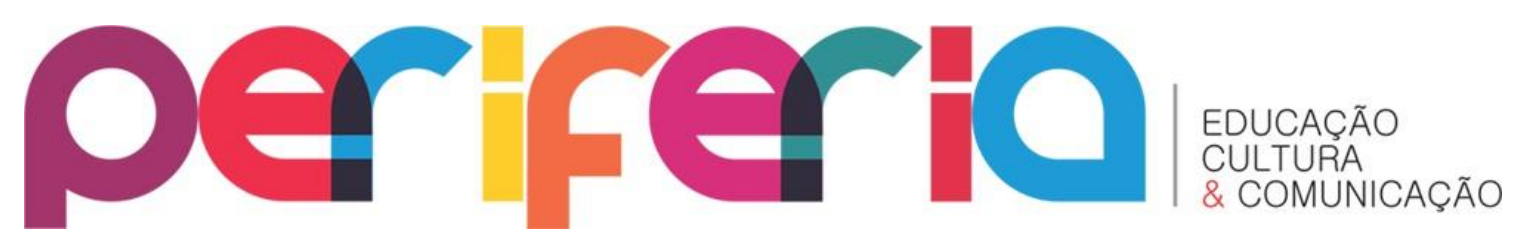

as finding a soul mate is to the rest of life. Do not wait until a mentor finds you; and

- Pay it forward. Offer to help junior or senior people to create mentorship moments.

Balancing the Act. Although women have been a prominent presence in the workplace for over five decades, the struggles surrounding work-life balance still drive some women to opt out of career opportunities. In many countries women now make up more than half of the populations at universities and in the work force, yet they are not advancing into the highest positions at the same rate as their male counterparts. Research shows that women are more likely to be successful at juggling multiple roles if their careers are meaningful and fulfilling. The art of work-life balance as a female leader requires careful planning and prioritization. Enlisting trusted family members and friends to help us accomplish the things we cannot do on our own is one of the best ways to achieve this. Having a support system at home can be a tremendous resource when we get caught with conflicting commitments between home and work.

Staying Put. The years when women are at the top of their careers are a time of consolidation, solidification, and fulfilment. It is a time when women can stretch themselves or gain greater depth in areas of interest. For example, in business that can be directorships, in politics it can be senior policy-making or influencing positions. Mentoring one another via peer relationships and networks can be very effective and satisfying. Having a close group of trusted friends and peers who can be frank, generous, and supportive of each other's success can help the goals that seem distant even at this point feel much more achievable.

And do not forget to:

- Master the art of delegation;

- Ask questions;

- Listen carefully but ignore negative comments;

- Accept that you will not know it all

- Communicate often;

- Create goals for yourself; and

- Develop strong peer relationships.

- Remember that you have earned this position.

Periferia, v. 10, n. 2, p. 217-230, jul./dez. 2018

DOI: 10.12957/periferia.2018.33265 


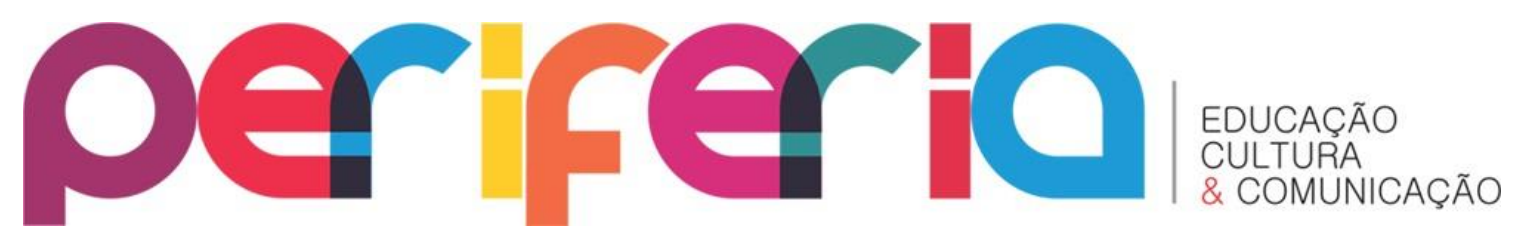

(Reilly) - What do you identify as the external barriers women face to progressing as leaders?

(Mahmood) - I consider the external barriers to be gender bias, lack of support, organizational barriers, cultural barriers, and religious barriers.

Gender Bias - According to the patriarchal view of society which is pervasive globally, male and female genders are assigned different roles and the individuals are always viewed through the lens of gender. This includes the notion that men and women are fundamentally different in nature. This lens also provides a hierarchical structure whereby men dominate the public sphere while women are relegated to the private sphere. Thus, female leaders operating in a male dominated sphere are unfit due to their gender. Organizations need to monitor and measure promotion rates and address areas of underperformance, such as why are women less likely to be promoted into particular roles or departments. They can adopt a specific gender strategy and develop a targeted strategy with a strong business case related to the proportion of women progressing through the organization.

Lack of support - The support that women need at work is denied to them just because they are women. The interesting aspect is that it was the other women at home and at work who failed to support the concerning women than the men. Men tend not to extend support openly as those who want to help women at home are labelled 'feminists' and those who extend a hand at work are termed as 'flirtatious'. All women who reached somewhere had the support of their families especially the male members around them. (father or husband).

Organizational Barriers. Barbara Bergmann opined that organizational structures are designed to prevent women from climbing to the top. Organizational structures "steer away" women's potential for upward mobility by confining them to work roles that are considered to be "women's occupations." Many organizations still make women "wrong" (consciously or subconsciously) for their priorities and styles that clash with the dominant culture. Organizations should create safe spaces at work and support women's transitions to bigger roles and that efforts to encourage women's development 


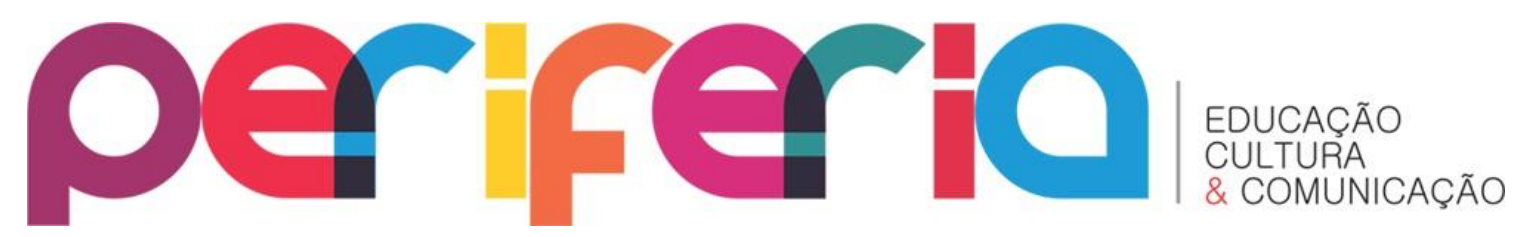

must be anchored in a push for better leadership. The aim is to change the whole environment.

Cultural Barriers. Lack of education and economic opportunities for women restrict the potential of women to think about their due rights. Furthermore, poverty and religious extremism are also roadblocks in the way of Women in many parts of the world like Pakistan are highly connected with the honour of men. Men normally control their movements and behaviour whether he is a father, husband or brother. The women of Pakistan will have to go a long way before they are able to get their rights in Pakistan.

Education is the only way forward. Education encompasses teaching and learning specific skills, and also something less tangible but more profound: the imparting of knowledge, good judgment and wisdom. It provides people with the tools and knowledge they need to understand and participate in today's world. Literacy provides girls and women with a greater understanding of basic health, nutrition and family planning, as well as of their own potential and it helps them long term as educated women marry later, have fewer children and receive better prenatal care.

(Reilly) - You mentioned religion as a barrier. Does Islam present opportunities or barriers for women?

(Mahmood) - All religions can present opportunities and obstacles. Islam is an example of a religion that has faced questions and concerns the role of women. Some Muslim countries offer very conservative interpretations of women's rights, while others are more aligned with what I believe are our rights. A woman has the right to own property, to own businesses, to keep her birth name, to choose her spouse, to divorce, to hold political office, and to enjoy equality with honor and respect. The right to work is also an inalienable right of women, which has never been prevented by Islam. If this right is denied, as it is in some Muslim societies, it will, as a consequence, deprive women the ability to make a choice in many areas and affect other interrelated rights such as mobility, decision making, and entering into politics. 


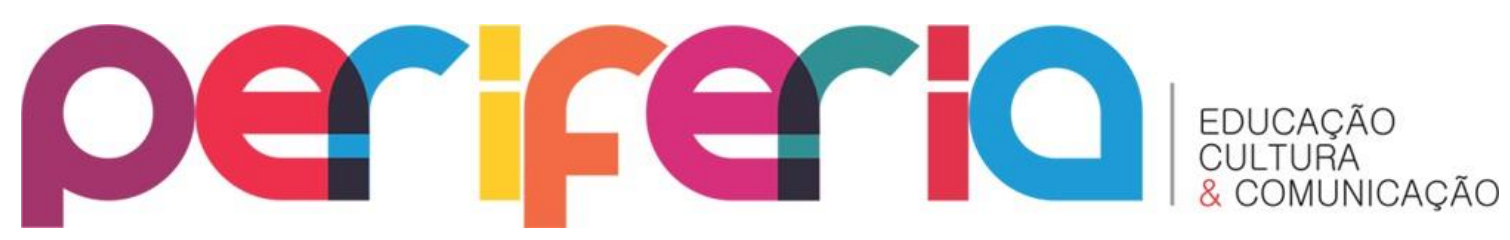

The first word of the Quran is "Iqra," which means "read"-and is meant for all individuals, not males alone. In many societies women are not given the right to education; they are made to believe in the cultural norms of the religion rather than the true meaning of Islam. The men, especially the religious leaders, are afraid that allowing women to read and write will lead to enlightenment and thus, moral degradation. Khadija, the first wife of the Prophet Muhammad, was one of the most successful traders of Makkah and many other examples Islamic history confirm that "women in business" are not frowned upon in Islam.

An educated woman understands the true meaning of religion and takes leadership roles within the context of her set cultural boundaries. The government, the media, the communities and in particularly the religious leaders need to work together and see the importance of women's participation in all walks of life.

(Reilly) - What are some gender-responsive economic policies for job creation?

(Mahmood) - The 2018 International Women's Day comes on the heels of unprecedented global movement for women's rights, equality, and justice. But more importantly, it was a day to call for an end to gender inequality in all its forms. Themed as, "Time is Now: Rural and Urban Activists Transforming Women's Lives," it came against a backdrop of a world that is undergoing major changes with significant implications for women. The economic conditions of women can only improve if we invest in their education and skills. We also need policies that enhance their productive capacities. As long as women remain less qualified than men, they are likely to remain in lower paying and less secure jobs. Giving more women access to education, skills, and technology, as well as bringing a change in attitudes and in socio-cultural norms, such as understanding the importance of sharing household chores, will also help women to spend time investing in expanding their capacities.

Women are the largest economic opportunity globally. The most convincing business case for women comes from Silverstein and Sayre, who in 


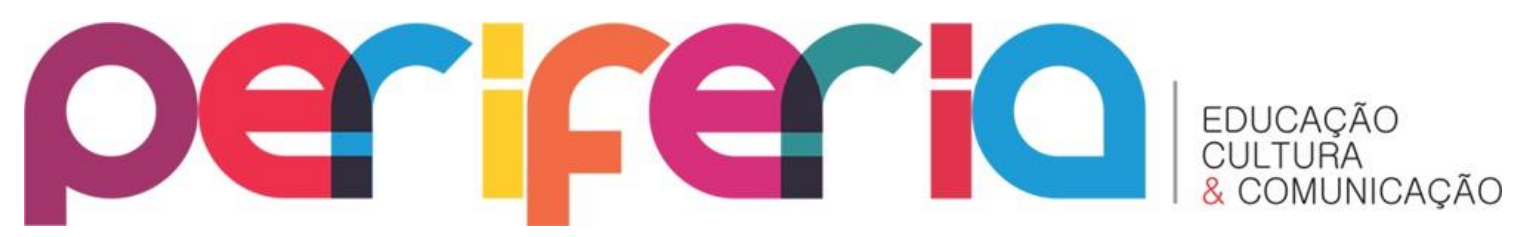

2009 demonstrated that women are a bigger economic opportunity than India and China combined. Many institutions now recognize that women's growing affluence and influence cannot be ignored and they have identified women as the next big market opportunity as they explore different ways of capturing and capitalizing on this market segment.

(Reilly) - What are your recommendations for poverty reduction and sustainable, inclusive growth?

(Mahmood) - The United Nations Sustainable Development Goals seek to change the course of the 21st century, addressing key challenges such as poverty, inequality, and violence against women. Goal Five is all about achieving gender equality and empower all women and girls. I offer five recommendations.

First, with full and equal participation of women, governments need to reassess and adapt macroeconomic and social policies with a view to extend women women's economic empowerment, leadership and participation. Second, develop a tool to measure inclusivity at county level and capacity development on gender responsive budgeting. Third, introduce microcredit/microfinance schemes to actively support women's empowerment. To mobilize new and additional financial resources that are both adequate and predictable and mobilized in a way that maximizes the availability of such resources and uses all available funding sources and mechanisms with a view to contributing towards the goal of poverty eradication and targeting women living in poverty.

A fourth recommendation is to mobilize all parties involved in the development process, national and international non-governmental organizations and women's groups, including academic institutions, nongovernmental organizations, grass-roots and women's groups. Finally, improve the effectiveness of anti-poverty programs directed towards the poorest and most disadvantaged groups of women, such as rural and indigenous women, female heads of household, young women and older women, refugees and migrant women and women with disabilities. 


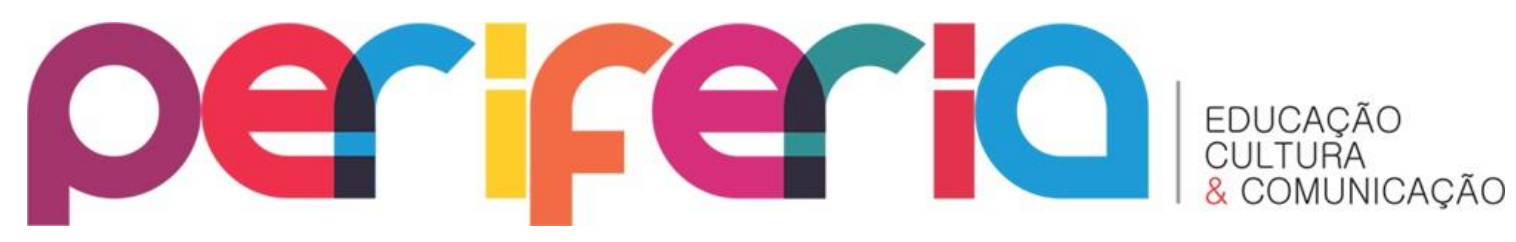

(Reilly) - Do you have a closing call to action for us?

(Mahmood) - Aude Zieseniss de Thuin, President and Founder of The Women's Forum for the Economy and Society, stated, "We cannot build a world which is livable if it walks only on one foot- continuing to neglect, by obscure prejudices, 50 percent of the talent, skill, and energy available." The world needs to pay attention to the gender gap not only because such inequality is intrinsically unfair but it also has a toll on the world economy. At the current rate of progress, the overall global gender gap will take a hundred years to close, while the gap in the workplace will not be closed for 217 years. It is a gap the world cannot afford to ignore. 